\title{
Above- and below-ground biomass accumulation, production, and distribution of sweetgum and loblolly pine grown with irrigation and fertilization
}

\author{
David R. Coyle, Mark D. Coleman, and Doug P. Aubrey
}

\begin{abstract}
Increased forest productivity has been obtained by improving resource availability through water and nutrient amendments. However, more stress-tolerant species that have robust site requirements do not respond consistently to irrigation. An important factor contributing to robust site requirements may be the distribution of biomass belowground, yet available information is limited. We examined the accumulation and distribution of above- and below-ground biomass in sweetgum (Liquidambar styraciflua L.) and loblolly pine (Pinus taeda L.) stands receiving irrigation and fertilization. Mean annual aboveground production after 4 years ranged from 2.4 to $5.1 \mathrm{Mg}^{\circ} \mathrm{ha}^{-1}$.year ${ }^{-1}$ for sweetgum and from 5.0 to $6.9 \mathrm{Mg} \cdot \mathrm{ha}^{-1} \cdot \mathrm{year}^{-1}$ for pine. Sweetgum responded positively to irrigation and fertilization with an additive response to irrigation + fertilization. Pine only responded to fertilization. Sweetgum root mass fraction (RMF) increased with fertilization at 2 years and decreased with fertilization at 4 years. There were no detectable treatment differences in loblolly pine RMF. Development explained from $67 \%$ to $98 \%$ of variation in shoot versus root allometry for ephemeral and perennial tissues, fertilization explained no more than $5 \%$ of the variation in for either species, and irrigation did not explain any. We conclude that shifts in allocation from roots to shoots do not explain nutrient-induced growth stimulations.
\end{abstract}

Résumé : Une augmentation de la productivité de la forêt a été obtenue en améliorant la disponibilité des ressources à l'aide d'amendements en eau et en nutriments. Cependant, les espèces plus tolérantes au stress ayant des exigences écologiques robustes ne réagissent pas de la même façon à l'irrigation. La distribution de la biomasse souterraine pourrait être un facteur important contribuant aux exigences écologiques robustes, mais peu d'information est disponible. Nous avons étudié l'accumulation et la distribution de la biomasse aérienne et souterraine dans des peuplements de copalme d'Amérique (Liquidambar styraciflua L.) et de pin à encens (Pinus taeda L.) irrigués et fertilisés. La production aérienne annuelle moyenne après quatre ans variait de 2,4 à $5,1 \mathrm{Mg} \cdot \mathrm{ha}^{-1} \cdot \mathrm{an}^{-1}$ dans le cas du copalme d'Amérique et de 5,0 à $6,9 \mathrm{Mg} \cdot \mathrm{ha}^{-1} \cdot \mathrm{an}^{-1}$ dans le cas du pin à encens. Le copalme d'Amérique a réagi positivement à l'irrigation et à la fertilisation tout en ayant une réaction additive lorsque ces deux traitements étaient appliqués. Le pin à encens a réagi uniquement à la fertilisation. La fraction de masse racinaire (FMR) du copalme d'Amérique augmentait avec la fertilisation après deux ans et diminuait avec la fertilisation après 4 ans. Nous n'avons pas détecté de différence significative entre les traitements dans le cas de la FMR du pin à encens. La croissance a expliqué de $67 \%$ à $98 \%$ de la variation de l'allométrie entre les pousses et les racines dans le cas des tissus éphémères et pérennes alors que la fertilisation n'a pas expliqué plus de $5 \%$ de la variation chez l'une ou l'autre des deux espèces et que l'irrigation n'a rien expliqué du tout. Nous concluons que le déplacement de l'allocation des racines vers les pousses n'explique pas la stimulation de la croissance induite par les nutriments.

[Traduit par la Rédaction]

\section{Introduction}

Forests constitute a large carbon sink; with the rise in global temperatures and atmospheric $\mathrm{CO}_{2}$, plantation forests have potential for carbon sequestration because of their rapid initial growth rates (Lemus and Lal 2005). With $13 \times$ $10^{6}$ ha of plantation pine forests, the southeastern United States is the vanguard of production forestry (Fox et al.

Received 22 May 2007. Accepted 28 November 2007. Published on the NRC Research Press Web site at cjfr.nrc.ca on 29 April 2008.

D.R. Coyle, ${ }^{1,2}$ M.D. Coleman, and D.P. Aubrey. USDA Forest Service, Southern Research Station, Savannah River Research Campus, 241 Gateway Drive, Aiken, SC, 29803, USA.

${ }^{1}$ Corresponding author (e-mail: dcoyle@entomology.wisc.edu). ${ }^{2}$ Present address: Department of Entomology, 345 Russell Laboratories, University of Wisconsin, Madison, WI, 53706 , USA.
2006). Increasing the productivity of plantation forests is a constant goal (Farnum et al. 1983) because increased timber production will decrease production costs, and subsequently wood product prices for the consumer (Siry and Bailey 2003), preserve natural forest areas (Sedjo and Botkin 1997), supply bioenergy fuels (Mead 2005), and increase carbon sequestration rates (Lemus and Lal 2005; Woodbury et al. 2007). Although Oren et al. (2001) caution that projected carbon sequestration rates may be overly optimistic because of soil nutrient limitations on plant productivity, it has been shown that intensive management practices such as fertilization and irrigation can mitigate limitations to site resource supply (Shan et al. 2001).

Sweetgum (Liquidambar styraciflua L.) and loblolly pine (Pinus taeda L.) are two native, commercially important timber species in the southeastern United States. Since 1920 , an eightfold increase in loblolly pine productivity has been realized because of use of intensive management, including the selection of genetic material, site preparation, 
fertilization, and pest management (Stanturf et al. 2003). Intensive management treatments have resulted in a 10-fold increase in sweetgum production (Nelson et al. 1995; Allen et al. 2005b). Resources drive productivity, especially on sites with limited availability. However, the extent to which resource availability drives productivity varies among tree species and site quality. For instance, both nutrient and water availability affected eastern cottonwood (Populus deltoides Bartr.) and American sycamore (Platanus occidentalis L.) productivity in the humid southeastern United States, where growing season precipitation is frequent and vapor pressure deficits are low (Lockaby et al. 1997; Coyle and Coleman 2005). Numerous studies suggest that nutrient, not water, availability is key for optimum sweetgum (Lockaby et al. 1997; Samuelson 1998) and pine (Jokela et al. 2004, and references therein) growth in the humid southeastern United States. Other studies suggest hardwoods, including sweetgum, will respond to irrigation (Allen et al. 2005a). Tolerance of xeric conditions by sweetgum would be consistent with its robust site requirements, similar to loblolly pine, and in contrast to the narrow high-resource requirements of cottonwood and sycamore. Therefore, comparing the response of sweetgum and loblolly pine with resource availability is important to understand the basis of their robust site requirements. Does the response of sweetgum to water and nutrient availability group functionally with more demanding hardwood species or with the more tolerant loblolly pine? We are not aware of side by side comparisons of sweetgum and loblolly pine where irrigation and fertilization have both been applied separately and in combination. One study has been conducted in the southeastern United States (Samuelson et al. 2004) that examined loblolly pine growth receiving similar irrigation and fertilization treatments: after 6 years, increasing resource availability greatly accelerated stand development and biomass accumulation.

Belowground biomass proportions in trees are affected by a combination of resource availability and age. Increased resource availability causes greater stem production, as a result of allocation to aboveground biomass components at the expense of roots (Linder 1989). This can be a desirable trait for productivity purposes and has been demonstrated in hardwoods (Barton and Montagu 2006) and conifers (Axelsson and Axelsson 1986; Albaugh et al. 1998). However, it is important to compare trees at developmentally, not chronologically, similar stages (Reich 2002; Coyle and Coleman 2005). The fraction of production that is allocated to belowground tissues decreases with stand age (Bernardo et al. 1998; Coyle and Coleman 2005). Fertilization can cause this shift in allocation to occur more quickly. Therefore, separating the effects of resource-induced versus age-related changes in biomass distribution is necessary to understand controlling factors (Ledig et al. 1970; Reich 2002). Distinguishing age-related controls of biomass distribution requires multiple sampling dates. Intensively managed forests provide an excellent model system to address questions regarding productivity and belowground biomass proportions in response to resource amendments, because rapid growth allows samples to be collected across time periods that are meaningful to stand development. Furthermore, forest plantations are much more uniform, because they can be located on sites with consistent soil characteristics, can be planted with identical genetic stock, and can receive cultural treatments that eliminate competing understory vegetation (e.g., Adegbidi et al. 2004; Coleman et al. 2004a). This uniformity minimizes variation and allows greater precision to distinguish temporal and environmental influences.

This study examined the above- and below-ground response of sweetgum and loblolly pine grown with a twoway factorial of irrigation and fertilization in an intensively managed forest plantation. We hypothesized that $(i)$ tree growth in the humid southeastern United States is limited more by nutrient availability than by water availability, and this will occur in both sweetgum and loblolly pine because both species are tolerant of a broad range of site conditions, and (ii) that belowground biomass proportions would be altered under different levels of resource availability in trees of the same age. Specifically, we predicted that lower amounts of biomass would be allocated to belowground tissues under increased resource availability.

\section{Materials and methods}

The site, plant materials, sampling methods, and experimental design were described previously (Coleman et al. 2004b; Coyle and Coleman 2005; Coleman 2007); a brief description follows.

\section{Site description and preparation}

The experiment was conducted at the US Department of Energy Savannah River Site, a National Environmental Research Park, located near Aiken, South Carolina, in the Carolina Sand Hill physiographic region $\left(33^{\circ} 23^{\prime} \mathrm{N}, 81^{\circ} 40^{\prime} \mathrm{E}\right)$. Previously, plantation pine with an oak understory grew on this predominately Blanton sand soil (Coleman et al. $2004 b$ ). Site preparation included homogenizing the forest floor, stumps, and all coarse woody debris $(<15 \mathrm{~cm}$ diameter) to a depth of $30 \mathrm{~cm}$. Pest control measures were used on all treatments, and understory vegetation was controlled completely with herbicides to eliminate concerns over belowground biomass accuracy. For experimental consistency, lime was applied to the entire site at a rate of $3.4 \mathrm{Mg} \cdot \mathrm{ha}^{-1}$ to increase soil $\mathrm{pH}$ to 6.5 (Coleman et al. 2004b). By choosing a site with consistent soils and low endemic moisture and nutrient levels, we were confident that our results were not confounded with other factors but were produced by the water and nutrient amendments.

\section{Plant material}

Four tree species were included in this experiment (Coleman et al. 2004b); here, we report results for sweetgum (half-sib family WV340 from Westvaco Corp., Summerville, South Carolina) and loblolly pine (half-sib family 7-56 from International Paper Co., Lumberton, North Carolina). Bareroot 1-0 seedlings were hand planted during February 2000.

\section{Experimental design}

Treatment plots $(0.22 \mathrm{ha})$ contained 294 trees planted at $2.5 \mathrm{~m} \times 3 \mathrm{~m}$ spacing; within a plot, the central 54 trees constituted the 0.04 ha measurement plot. Destructively harvested trees were chosen from large borders located on the ends of each plot. Treatments consisted of control (C), irrigation (I), fertilization (F), and irrigation + fertilization (IF). 
Within each of three blocks, the four treatment plots were replicated with all plots of a given species grouped together to minimize within-block site gradients in a randomized complete block factorial design (Coleman et al. 2004b). Drip irrigation applied up to $5 \mathrm{~mm}$ of water daily to meet evaporative demand. During the reporting period, mean annual rainfall at the site was $982 \mathrm{~mm}$. A mean of $494 \mathrm{~mm}$ of additional water was supplied to irrigated plots during the 2000-2003 growing seasons. We applied a complete liquid fertilizer through the drip irrigation at rates of $40 \mathrm{~kg} \mathrm{~N} \cdot \mathrm{ha}^{-1}$.year ${ }^{-1}$ in years 1 and 2 , and $80 \mathrm{~kg} \mathrm{~N} \cdot \mathrm{ha}^{-1} \cdot$ year $^{-1}$ in years 3 and 4 . Increasing annual application rates correspond with increasing demand of growing trees. Other nutrients were applied in balance with $\mathrm{N}$ at the following rates $\left(\mathrm{kg} \cdot \mathrm{ha}^{-1} \cdot \mathrm{year}^{-1}\right)$ in year 1 and 2 and doubled in years 3 and $4: \mathrm{P}, 22 ; \mathrm{K}, 42 ; \mathrm{B}, 1.57 ; \mathrm{Mn}, 0.35 ; \mathrm{Zn}$, $0.21 ; \mathrm{Cu}, 0.07$; Mo, 0.00071 (Coleman et al. 2004b); the main exception was that $P$ was not included in years 2 and 4. Annual fertilizer treatments were applied in 26 weekly applications with the drip irrigation system, except that $P$ in year 3 was applied as a single spring application. To maintain experimental control, $5 \mathrm{~mm}$ water.week ${ }^{-1}$ was applied to nonfertilized plots, because the same amount was required to deliver fertilizer and flush drip tubes in fertilized plots. Consequently, an additional $130 \mathrm{~mm}$ of water was delivered to nonirrigated treatment plots (i.e., $\mathrm{C}$ and F) annually. All treatments were applied from 1 April to 30 September during 2000-2003.

\section{Growth measurements}

Basal diameter, height, and diameter at breast height $(\mathrm{DBH}, 1.37 \mathrm{~m})$ were recorded on all living trees in each measurement plot following the 2000-2003 growing seasons. Biomass was based on basal diameter in 2001 and on DBH in 2003.

\section{Fine root biomass}

We randomly sampled five locations for fine root biomass ( $<5 \mathrm{~mm}$ diameter) in each plot during November 2001 and 2003. A detailed description of fine-root biomass sampling methods is provided by Coleman (2007). Briefly, we removed $4.9 \mathrm{~cm}$ diameter cores from $0-15,15-45$, and $45-$ $105 \mathrm{~cm}$ depths. Roots were elutriated from soil (Gillison's Variety Fabrication, Inc., Benzonia, Michigan), and live roots $(<5 \mathrm{~mm})$ were then manually separated from remaining organic matter, dried $\left(60^{\circ} \mathrm{C}\right)$, and weighed.

\section{Dormant biomass}

Whole-tree destructive harvests were conducted during dormancy following the 2001 and 2003 growing seasons. Within a species, five trees (one or two per plot) were sampled in each treatment. The sample trees for a treatment were stratified based on diameter, so the entire size range of each species by treatment combination was represented.

Aboveground biomass was separated into branch and stem (and leaf for loblolly pine) components for each sample tree. The entire tissue sample was collected from each tree in 2001. Stem, branch, and leaf fresh masses were measured in the field in 2003, and representative subsamples were removed to determine water mass. All tissues were dried to constant mass at $60{ }^{\circ} \mathrm{C}$ prior to weighing. To determine the relative proportions of bark and wood, bark was separated from the wood in a $5 \mathrm{~cm}$ segment at the top, middle, and bottom third of each stem. Total stem dry mass was multiplied by this proportion to estimate total bark and wood biomass.

We separated woody belowground biomass into stump and coarse root components. Stumps were removed using a mechanical tree spade (model TS34C; Bobcat Co., West Fargo, North Dakota). A total volume of $0.18 \mathrm{~m}^{3}$ was removed, which was a cone of $1 \mathrm{~m}$ diameter and $0.69 \mathrm{~m}$ depth. Soil was rinsed off and coarse roots ( $>5 \mathrm{~mm}$ diameter) removed. Whole stumps were dried and weighed in 2001, whereas fresh stump masses were measured in the field with subsamples removed to determine water mass in 2003 . We estimated peripheral coarse root biomass by digging three random $0.19 \mathrm{~m}^{2}$ holes that were $30 \mathrm{~cm}$ deep within the sampled tree's growing space yet outside of the $1 \mathrm{~m}^{2}$ stump sampling area (Coleman 2007). All coarse roots $(>5 \mathrm{~mm}$ ) were collected from the samples and soil was rinsed prior to drying and weighing. No roots greater than $5 \mathrm{~mm}$ diameter were seen exiting the bottom of these coarse root sampling locations.

\section{Biomass calculations and statistical analysis}

We used power functions with diameter as the independent variable (Parresol 1999; Coyle and Coleman 2005) to estimate leaf (loblolly pine only), bark, wood, branch, stump, and coarse root biomass for all live trees in each plot. We calculated individual tree biomass values as a function of diameter by performing nonlinear regression (PROC NLIN; SAS Institute Inc., Cary, North Carolina) and scaled to an area basis by summing the biomass values for all live measurement plot trees and dividing by plot area. Sweetgum leaf biomass was estimated from leaf litter collections taken from three $0.22 \mathrm{~m}^{2}$ baskets per plot; loblolly pine leaf litter was collected in the same manner and also added to live pine leaf biomass. Litter was collected monthly and dried to constant mass at $60{ }^{\circ} \mathrm{C}$ prior to weighing. Plot means were obtained from the three baskets and expressed on an area basis. Shoot biomass was the sum of branch, bark, and wood biomass; leaf biomass was also included for loblolly pine. Root biomass was the sum of stump, coarse root, and fine root biomass. Although we present regression parameters for shoot, root, and total biomass, we analyzed these variables by summing the individual tissue components. This approach allowed us to include fine root biomass and leaf litter-variables that, because of the sampling scheme, could not be attributed to a single individual as the other variables could. Root mass fraction (RMF) was calculated as root biomass/total biomass. Mean annual production (aboveground, belowground, and total) was calculated as biomass (shoot, root, and total, respectively) divided by the number of growing seasons.

We used plot means (i.e., plot considered as the experimental unit) to analyze biomass components. This method adequately accounts for variance among plot means but eliminates variance among sample trees used to develop regression equations (Parresol 1999). Therefore, the total variance used in the ANOVA may have been less than that among sample trees. We assumed that individual tree variance equilibrates according to the central limit theorem because of the large number of trees per plot $(n=54)$.

We analyzed species and treatment effects in a three-way among-subjects factorial split plot over time. The statistical model was 


$$
\begin{aligned}
Y_{i j k l}=\mu+\alpha_{i}+\beta_{j}+\gamma_{k}+\delta_{l}+(\alpha \beta)_{i j}+(\alpha \gamma)_{i k}+(\alpha \delta)_{i l}+(\beta \gamma)_{j k}+(\beta \delta)_{j l} & +(\gamma \delta)_{k l}+(\alpha \beta \gamma)_{i j k}+(\alpha \beta \delta)_{i j l} \\
& +(\alpha \gamma \delta)_{i k l}+(\beta \gamma \delta)_{j k l}+(\alpha \beta \gamma \delta)_{i j k l}+\omega_{m}+(\omega \alpha)_{i m}+\epsilon_{i j k l}
\end{aligned}
$$

where $i$ is the species effect, $j$ is the fertilization effect, $k$ is the irrigation effect, $l$ is the year effect, and $m$ is the block effect. In this model, species was treated as the fixed wholeplot factor; block was treated as a random factor, whereas irrigation and fertilization were treated as fixed subplot factors. The crossing of block $(\omega)$ and species $(\alpha)$ in the model signifies that the interaction of these two factors will be used as the error term for the whole-plot factor. Biomass for various tissue components, mean annual production, and $\mathrm{RMF}$ were analyzed using the above model. In 2001, many measurement trees were not large enough for DBH measurements; therefore, we analyzed height, diameter, and basal area using only 2003 data in a similar model without the year factor.

Repeated measures analyses require that the covariance structure be modeled for each response variable. Therefore, we analyzed each response using common covariance structures and used Akaike's information corrected criterion (Burnham and Anderson 1998) to determine which structure best fit each model. Denominator degrees of freedom were computed according to the Kenward-Roger method (Kenward and Roger 1997). All analyses were performed using. the mixed-model procedure (PROC MIXED) of SAS (version 9.1.3; SAS Institute Inc., Cary, North Carolina) with a type-I error rate of 0.05 . Treatment means were compared using Fisher's least significant difference (LSD) test. When interactions occurred, we performed tests of simple main effects using the SLICE option in the LSMEANS statement of PROC MIXED (Schabenberger et al. 2000; Littell et al. 2006). We performed Shapiro-Wilk tests (the SAS UNIVARIATE procedure) to test the assumption of normality. Repeated measures analyses (PROC MIXED) account for correlations within experimental units through time as well as possible heterogeneity of variances within experimental units. RMF data are proportional and presented as such throughout the report; however, data were arcsine square root transformed to achieve normality for statistical tests (Zar 1996).

We used allometric relationships to distinguish effects of development from resource availability on biomass allocation (Ledig et al. 1970; Hunt 1978; Coleman et al. 2004a) using the linear form of the model $y=a x^{k}$ :

$$
\text { [1] } \quad \ln y=a^{\prime}+k^{\prime} \ln x
$$

where $x$ and $y$ are the compared tissue components, and $a^{\prime}$ and $k^{\prime}$ are predicted parameters. Differences in the allometric coefficient, $k^{\prime}$, among treatments indicate changes in allocation (Hunt 1978). When $y$ represents the belowground fraction, an increase in $k$ is due to a greater root fraction. We examined coefficients of factors within ANCOVA models to examine differences among treatments (Coyle and Coleman 2005). Differences in $k^{\prime}$ among treatments were identified by a significant interaction between treatment fac- tors and the covariate. We tested treatment differences in $k^{\prime}$ using the estimate statement in PROC MIXED (Littell et al. 2006). We used a stepwise multiple regression to assess the combined explanatory power of development and treatment effects on allometric relationships (the SAS REG procedure). Relationships were analyzed for woody root versus woody shoot (i.e., coarse root and stump vs. bark, wood, and stump); ephemeral root versus ephemeral shoot (i.e., fine root vs. leaf); and the combination of woody and ephemeral tissues. We used leaf litter for the sweetgum analyses and the combination of leaf litter and leaf for loblolly pine. Saturated models included biomass, fertilization, and irrigation; irrigation was not included in any of the the final models and, therefore, was left out of the results table. We analyzed these relationships separately for each species using log-transformed biomass values. We performed residual analyses by plotting residuals versus predicted values and retained all data points $(n=24)$ in the final models. An alpha of 0.10 was the significance level used for parameter inclusion.

\section{Results}

\section{Four-year stand characteristics}

For a given treatment, diameter and basal area differed significantly between species, but height did not (Table 1). Loblolly pine diameter was $22 \%$ larger, and basal area was $49 \%$ larger than in sweetgum. Trees in fertilized treatments (F and IF) had 28\% larger diameter, 61\% larger basal area, and $19 \%$ larger height than nonfertilized treatments (C and I) (Table 1). Neither irrigation nor any interaction between species, fertilization, nor irrigation was significant for any stand characteristic at 4 years of age (Table 1 ).

\section{Annual biomass production}

Mean annual production was similarly affected by species, sample period, and treatments. Aboveground mean annual production was similar between species after 2 years but was larger in loblolly pine than sweetgum after 4 years $(\mathrm{Y} \times \mathrm{S}$ interaction, Table 2 ), whereas belowground mean annual production was larger in sweetgum at both sampling periods ( $\mathrm{S}$ main effect, Table 2 ). Total mean annual production was similar between species after 2 years and was larger in loblolly pine after 4 years $(\mathrm{Y} \times \mathrm{S}$ interaction, Table 2). Aboveground, belowground, and total mean annual production was positively affected by fertilization in both species and the magnitude of response increased with age ( $\mathrm{Y} \times \mathrm{F}$ interaction, Table 2 ). Total mean annual production rates were $>63 \%$ higher in trees receiving fertilization compared with unfertilized trees. Irrigation did not result in increased aboveground or total mean annual production but did result in increased belowground mean annual production in sweetgum, whereas loblolly pine exhibited no response 
Table 1. Stand characteristics of sweetgum and loblolly pine after four growing seasons.

\begin{tabular}{lccc}
\hline & \multicolumn{3}{l}{ Basal area } \\
$\left(\mathrm{m}^{2} \cdot \mathrm{ha}^{-1}\right)$ & Height $(\mathrm{m})$ \\
\hline Sweetgum & & & \\
C & $6.1 \pm 0.1 \mathrm{c}$ & $3.9 \pm 0.1 \mathrm{c}$ & $5.3 \pm 0.0 \mathrm{c}$ \\
I & $6.5 \pm 0.6 \mathrm{bc}$ & $4.7 \pm 0.9 \mathrm{bc}$ & $5.7 \pm 0.3 \mathrm{bc}$ \\
F & $7.5 \pm 0.3 \mathrm{ab}$ & $6.1 \pm 0.4 \mathrm{ab}$ & $6.0 \pm 0.2 \mathrm{ab}$ \\
IF & $8.4 \pm 0.1 \mathrm{a}$ & $7.6 \pm 0.3 \mathrm{a}$ & $6.8 \pm 0.2 \mathrm{a}$ \\
Mean & $7.1 \pm 0.3$ & $5.6 \pm 0.5$ & $5.9 \pm 0.2$ \\
Loblolly pine & & & \\
C & $7.9 \pm 0.9 \mathrm{~b}$ & $7.0 \pm 1.5 \mathrm{~b}$ & $5.5 \pm 0.5 \mathrm{~b}$ \\
I & $7.3 \pm 0.3 \mathrm{~b}$ & $5.7 \pm 0.6 \mathrm{~b}$ & $5.1 \pm 0.2 \mathrm{~b}$ \\
F & $9.7 \pm 0.2 \mathrm{a}$ & $10.1 \pm 0.4 \mathrm{a}$ & $6.3 \pm 0.1 \mathrm{a}$ \\
IF & $9.8 \pm 0.2 \mathrm{a}$ & $10.5 \pm 0.4 \mathrm{a}$ & $6.4 \pm 0.2 \mathrm{a}$ \\
Mean & $8.7 \pm 0.4$ & $8.3 \pm 0.7$ & $5.8 \pm 0.2$ \\
Effect $(P$ value $)$ & & & \\
Species (S) & $\mathbf{0 . 0 3 3 9}$ & $\mathbf{0 . 0 3 0 5}$ & 0.5627 \\
Irrigation (I) & 0.4378 & 0.5036 & 0.2740 \\
Fertilization (F) & $<\mathbf{0 . 0 0 0 1}$ & $<\mathbf{0 . 0 0 0 1}$ & $<\mathbf{0 . 0 0 0 1}$ \\
S $\times$ I & 0.1655 & 0.1284 & 0.0564 \\
S $\times$ F & 0.4352 & 0.1825 & 0.6632 \\
I $\times$ F & 0.3552 & 0.2657 & 0.2906 \\
S $\times$ I $\times$ F & 0.8044 & 0.6493 & 0.8768 \\
\hline N &
\end{tabular}

Note: Values for stand characterisitics are means \pm SEs. Treatments consisted of control (C), irrigation (I), fertilization (F), and irrigation + fertilization (IF). Values with the same letter are not significantly different (Fisher's LSD, $\alpha=0.05$ ). The $P$ values for the main effects and their interaction are presented below each species. Those with $\alpha<0.05$ are given in boldface.

$(\mathrm{S} \times \mathrm{I}$ interaction, Table 2). Aboveground mean annual production was $24 \%$ larger than belowground in sweetgum and $62 \%$ larger in loblolly pine.

\section{Biomass accumulation}

Biomass components of harvested trees were well correlated with stem diameter. The parameters for equations used to calculate biomass and their correlation coefficients from the 2003 harvest data are provided in Appendix A.

Biomass differed between species and the relative ranking changed over time. After two growing seasons, sweetgum total biomass was $83 \%$ larger than loblolly pine; however, after four growing seasons, total biomass between the two species was nearly identical $(\mathrm{Y} \times \mathrm{S}$ interaction, Table 3 and Fig. 1). After 2 years, sweetgum total biomass ranged from 3.4 to $7.1 \mathrm{Mg} \cdot \mathrm{ha}^{-1}$, whereas pine total biomass ranged

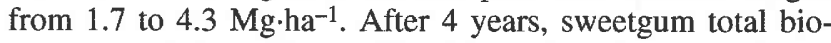
mass ranged from 21.9 to $40.8 \mathrm{Mg} \cdot \mathrm{ha}^{-1}$, and pine total biomass ranged from 22.6 to $41.6 \mathrm{Mg} \cdot \mathrm{ha}^{-1}$. Shoot biomass was similar between species after 2 years but larger in loblolly pine after 4 years $(\mathrm{Y} \times \mathrm{S}$ interaction, Table 3$)$. Sweetgum root biomass was greater than loblolly pine at both sampling periods but the magnitude of difference decreased between 2 and 4 years $(\mathrm{Y} \times \mathrm{S}$ interaction, Table 3$)$.

The ranking of biomass components also changed over time. There was a shift from predominately ephemeral leaf and fine root components in the 2001 harvest to woody perennial components in 2003. For example, sweetgum belowground biomass consisted of $47 \%$ fine roots after 2 years and of only $27 \%$ after 4 years. In loblolly pine after 2 years,
Table 2. Annual production $\left(\mathrm{Mg} \cdot \mathrm{ha}^{-1} \cdot \mathrm{year}^{-1}\right)$ of sweetgum and loblolly pine after four growing seasons.

\begin{tabular}{lccc}
\hline & Aboveground & Belowground & Total \\
\hline Sweetgum & & & \\
C & $2.4 \pm 0.1 \mathrm{~b}$ & $2.3 \pm 0.1 \mathrm{~b}$ & $4.7 \pm 0.1 \mathrm{c}$ \\
I & $2.6 \pm 0.6 \mathrm{~b}$ & $2.5 \pm 0.3 \mathrm{~b}$ & $5.1 \pm 0.9 \mathrm{bc}$ \\
F & $3.8 \pm 0.2 \mathrm{ab}$ & $3.5 \pm 0.1 \mathrm{a}$ & $7.3 \pm 0.4 \mathrm{ab}$ \\
IF & $5.1 \pm 0.2 \mathrm{a}$ & $3.8 \pm 0.2 \mathrm{a}$ & $8.9 \pm 0.4 \mathrm{a}$ \\
Average & $4.5 \pm 0.5$ & $3.0 \pm 0.2$ & $7.5 \pm 0.7$ \\
Loblolly pine & & & \\
C & $5.0 \pm 1.1 \mathrm{ab}$ & $1.9 \pm 0.3 \mathrm{~b}$ & $6.9 \pm 1.4 \mathrm{ab}$ \\
I & $4.1 \pm 0.4 \mathrm{~b}$ & $1.4 \pm 0.1 \mathrm{~b}$ & $5.5 \pm 0.5 \mathrm{~b}$ \\
F & $7.5 \pm 0.5 \mathrm{a}$ & $2.7 \pm 0.1 \mathrm{a}$ & $10.3 \pm 0.6 \mathrm{a}$ \\
IF & $6.9 \pm 0.3 \mathrm{ab}$ & $2.8 \pm 0.2 \mathrm{a}$ & $9.7 \pm 0.5 \mathrm{a}$ \\
Average & $6.0 \pm 0.5$ & $2.2 \pm 0.2$ & $8.2 \pm 0.7$ \\
Effect & & & \\
Year (Y) & $<\mathbf{0 . 0 0 0 1}$ & $<\mathbf{0 . 0 0 0 1}$ & $<\mathbf{0 . 0 0 0 1}$ \\
Species (S) & $\mathbf{0 . 0 1 2 7}$ & $<\mathbf{0 . 0 0 0 1}$ & 0.6031 \\
Irrigation (I) & 0.5191 & 0.2337 & 0.4243 \\
Fertilization (F) & $<\mathbf{0 . 0 0 0 1}$ & $<\mathbf{0 . 0 0 0 1}$ & $<\mathbf{0 . 0 0 0 1}$ \\
Y $\times$ S & $\mathbf{0 . 0 0 0 3}$ & 0.7656 & $\mathbf{0 . 0 0 1 4}$ \\
Y $\times$ I & 0.3849 & $\mathbf{0 . 0 6 5 2}$ & 0.2453 \\
Y $\times$ F & $<\mathbf{0 . 0 0 0 1}$ & $<\mathbf{0 . 0 0 0 1}$ & $<\mathbf{0 . 0 0 0 1}$ \\
S $\times$ I & $\mathbf{0 . 0 9 9 0}$ & $\mathbf{0 . 0 2 6 1}$ & 0.0670 \\
S $\times$ F & 0.5473 & $\mathbf{0 . 0 4 8 4}$ & 0.9326 \\
I $\times$ F & 0.1794 & 0.1277 & 0.1579 \\
Y $\times$ S $\times$ I & 0.1696 & 0.3923 & \\
Y $\times$ S $\times$ F & 0.7205 & 0.0832 & \\
Y $\times$ I $\times$ F & 0.8516 & 0.5955 & \\
S $\times$ I $\times$ F & 0.6329 & 0.4789 & 0.8574 \\
Y $\times$ S $\times$ I $\times$ F & 0.6287 & 0.3460 & 0.8577 \\
\hline Note See Table & &
\end{tabular}

Note: See Table 1 for treatment abbreviations. Values for annual production are means \pm SEs. Belowground production does not include fine-root turnover and, therefore, is an underestimate. Values with the same letter are not significantly different (Fisher's LSD, $\alpha=0.05$ ). The $P$ values for the main effects and their interaction are presented below each species. Those with $\alpha<0.05$ are given in boldface.

leaves comprised $49 \%$ of aboveground biomass, and fine roots comprised $45 \%$ of belowground biomass. After 4 years, leaves comprised only $26 \%$ of aboveground biomass, and fine roots comprised $18 \%$ of belowground biomass.

Biomass components responded positively to fertilization with few exceptions. Composite (shoot, root, and total) tissues responded positively to fertilization in both species and the magnitude of response increased with age $(\mathrm{Y} \times \mathrm{F}$ interaction, Table 3). Individual tissues (leaf, bark, wood, branch, stump, coarse root, and fine roots) generally responded positively to fertilization, and the magnitude of the response increased with age except for fine roots $(\mathrm{Y} \times \mathrm{F}$ interaction, Table 3). However, sweetgum leaf and bark tissue did not respond positively after 2 years, and fine root tissue did not respond positively after 4 years, whereas loblolly pine fine root tissue did not respond after 2 years $(\mathrm{Y} \times \mathrm{S} \times \mathrm{F}$ interaction, Table 3).

Irrigation elicited some positive biomass responses in sweetgum and some negative biomass responses in loblolly pine, both of which were more pronounced belowground. Composite root tissue responded with $11 \%$ larger biomass in sweetgum receiving $I$ relative to $C$ treatments, whereas loblolly pine receiving I experienced a $26 \%$ reduction rela- 
Table 3. Significance levels for biomass components after 4 years of resource amendment treatments.

\begin{tabular}{|c|c|c|c|c|c|c|c|c|c|c|}
\hline Effect & Leaf & Bark & Wood & Branch & Stump & $\begin{array}{l}\text { Coarse } \\
\text { root }\end{array}$ & $\begin{array}{l}\text { Fine } \\
\text { root }\end{array}$ & $\begin{array}{l}\text { Total } \\
\text { shoot }^{a}\end{array}$ & $\begin{array}{l}\text { Total } \\
\operatorname{root}^{b}\end{array}$ & $\begin{array}{l}\text { Total } \\
\text { biomass }^{c}\end{array}$ \\
\hline Year (Y) & $<0.0001$ & $<0.0001$ & $<0.0001$ & $<0.0001$ & $<0.0001$ & $<0.0001$ & $<0.0001$ & $<0.0001$ & $<0.0001$ & $<0.0001$ \\
\hline Species (S) & $<0.0001$ & $<0.0001$ & 0.3214 & 0.3595 & 0.0795 & $<0.0001$ & $<0.0001$ & 0.0051 & $<0.0001$ & 0.7513 \\
\hline Irrigation (I) & 0.5487 & 0.6409 & 0.1201 & 0.7814 & 0.8427 & 0.1909 & 0.9880 & 0.7352 & 0.4979 & 0.6687 \\
\hline Fertilization (F) & 0.0007 & $<0.0001$ & $<0.0001$ & 0.0002 & $<0.0001$ & $<0.0001$ & $<0.0001$ & $<0.0001$ & $<0.0001$ & $<0.0001$ \\
\hline$Y \times S$ & 0.0003 & $<0.0001$ & 0.0192 & 0.0102 & 0.0771 & 0.0019 & 0.0010 & 0.0007 & 0.0027 & 0.0224 \\
\hline $\mathrm{Y} \times \mathrm{I}$ & 0.4307 & 0.0196 & 0.4308 & 0.1860 & 0.0839 & 0.5179 & 0.1326 & 0.6615 & 0.3490 & 0.5697 \\
\hline$Y \times F$ & 0.0054 & $<0.0001$ & $<0.0001$ & 0.0008 & $<0.0001$ & $<0.0001$ & 0.8872 & $<0.0001$ & $<0.0001$ & $<0.0001$ \\
\hline$S \times I$ & 0.8136 & 0.0196 & 0.0321 & 0.0964 & 0.9450 & 0.0002 & 0.3430 & 0.1034 & 0.0370 & 0.0767 \\
\hline$S \times F$ & 0.2938 & 0.0002 & 0.4125 & 0.8982 & 0.3003 & 0.2680 & 0.1949 & 0.6794 & 0.1546 & 0.9647 \\
\hline $\mathrm{I} \times \mathrm{F}$ & 0.3522 & 0.9197 & 0.0513 & 0.7722 & 0.0307 & 0.3297 & 0.6701 & 0.2555 & 0.1573 & 0.2208 \\
\hline $\mathrm{Y} \times \mathrm{S} \times \mathrm{I}$ & 0.6974 & 0.0107 & 0.0497 & 0.1992 & 0.2245 & 0.0002 & 0.0340 & 0.1332 & 0.1466 & 0.1242 \\
\hline $\mathrm{Y} \times \mathrm{S} \times \mathrm{F}$ & 0.0304 & 0.0002 & 0.6070 & 0.8935 & 0.7140 & 0.3949 & 0.0215 & 0.9406 & 0.5961 & 0.9502 \\
\hline $\mathrm{Y} \times \mathrm{I} \times \mathrm{F}$ & 0.6276 & 0.4101 & 0.1511 & 0.7505 & 0.0562 & 0.7047 & 0.9214 & 0.5772 & 0.3444 & 0.5053 \\
\hline $\mathrm{S} \times \mathrm{I} \times \mathrm{F}$ & 0.7141 & 0.1842 & 0.3148 & 0.7571 & 0.8243 & 0.7709 & 0.1557 & 0.6240 & 0.4326 & 0.8548 \\
\hline $\mathrm{Y} \times \mathrm{S} \times \mathrm{I} \times \mathrm{F}$ & 0.6777 & 0.0974 & 0.3087 & 0.7853 & 0.8876 & 0.4027 & 0.4608 & 0.6189 & 0.3517 & 0.8538 \\
\hline
\end{tabular}

Note: $P$ values with $\alpha<0.05$ are given in boldface.

${ }^{a}$ Total shoot $=$ branch + bark + wood + leaf; leaf litter was used as a surrogate for leaf biomass in sweetgum because harvests were conducted in the dormant season.

${ }^{b}$ Total root $=$ stump + coarse root + fine root.

'Total biomass $=$ total shoot + total root.

Fig. 1. Total dormant biomass of sweetgum and loblolly pine after four growing seasons. Treatments consisted of control (C), irrigation (I), fertilization (F), and irrigation + fertilization (IF). Zero on the $y$ axis represents the groundline. Error bars are SEs. Lowercase letters and error bars above the columns are for total aboveground biomass; those below the columns are for total belowground biomass. Capital letters above the $x$ axis refer to total biomass. Within a species, aboveground, belowground, or total biomass means with the same letter are not significantly different (Fisher's LSD, $\alpha=0.05$ ).

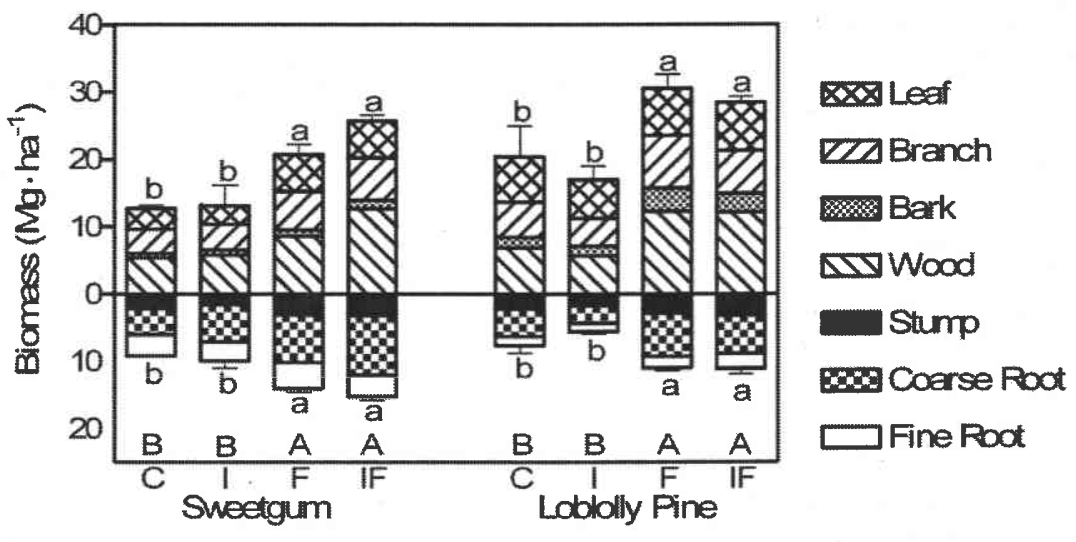

tive to $\mathrm{C}$ treatments $(\mathrm{S} \times \mathrm{I}$ interaction, Table 3 ). Irrigation resulted in increased wood and coarse root tissue biomass in sweetgum in both sampling periods $(\mathrm{S} \times \mathrm{I}$ interaction, Table 2). Irrigation increased sweetgum bark biomass at 2 years but reduced loblolly pine bark and coarse root biomass at 4 years $(\mathrm{Y} \times \mathrm{S} \times \mathrm{I}$ interaction, Table 3$)$.

\section{Belowground biomass proportion}

RMF responded to treatments differently according to species and sampling time $(\mathrm{Y} \times \mathrm{S} \times \mathrm{F}$ interaction, $P=$ 0.0038 ). RMF was always larger in sweetgum than in loblolly pine and generally decreased with age in both species (Fig. 2). Fertilization increased sweetgum RMF at 2 years and reduced RMF at 4 years but did not affect loblolly pine (Fig. 2). Irrigation did not affect RMF of either species.

Allometric relationships demonstrate that relative belowground biomass distribution was predominantly controlled by stand development $(P<0.0001)$ (Table 4$)$. The allometric coefficient, $k^{\prime}$, derived from these relationships (eq. 2) shows that, in sweetgum, there were important treatment effects, primarily because of fertilizer (Table 5). Treatments caused little or no response in loblolly pine (Table 5). In sweetgum, we observed decreased $k^{\prime}$ with fertilization, which indicates a greater proportion of the biomass occurred in shoots (Fig. 3). A similar response was observed when sweetgum fine roots were compared allometrically with 
Fig. 2. Sweetgum and loblolly pine root mass fraction (RMF) in response to fertilization for two sampling dates. Treatment means within a species with the same letter are not significantly different (Fisher's LSD, $\alpha=0.05$ ).

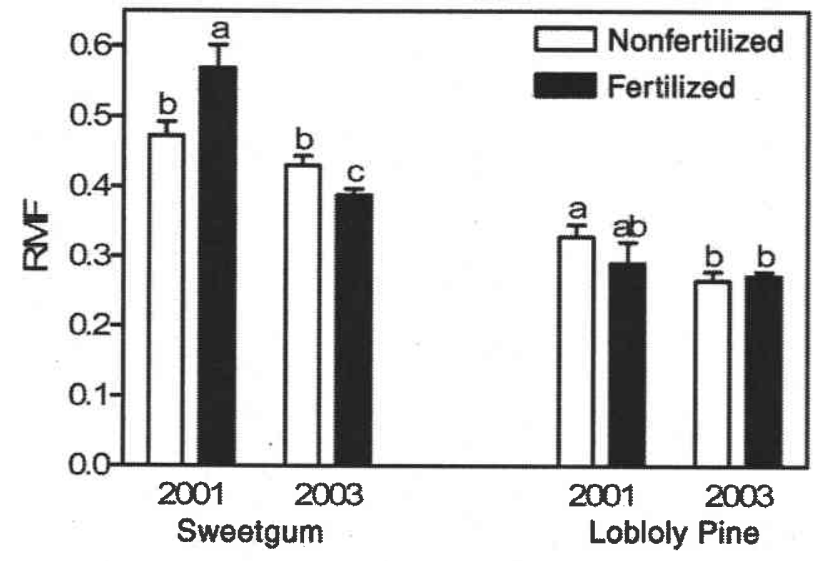

leaves and when woody root tissues were compared with woody shoot tissues (Table 5). Treatment differences in allometric relationships allow us to determine the relative amount of variation explained by development compared with resource availability. When considering woody perennial belowground versus aboveground biomass, developmental factors explained $98 \%$ of the variation in sweetgum and $99 \%$ of the variation in loblolly pine $(P<0.0001)$; fertilization only explained $0.3 \%$ of the variation in sweetgum and $0.1 \%$ in pine. For ephemeral tissues (fine root vs. leaf), development explained $67 \%$ of the variation in sweetgum and $78 \%$ of the variation in loblolly pine $(P<0.0001)$; fertilization explained $5 \%$ of the ephemeral tissue variation in sweetgum but did not explain any variation in loblolly pine. The amount of total root versus total shoot biomass explained was intermediate, because they are a mix of woody and ephemeral tissues.

\section{Discussion}

\section{Effect of resource amendments on growth and} production

Increased nutrient availability had a greater positive effect than did water availability on the growth and productivity of both tree species, thus supporting our first hypothesis. Tree productivity in both species was positively affected by fertilization. The southeastern United States has a very humid climate with regular growing season precipitation and low vapor pressure deficits; consequently, nutrient, not water, availability is often the limiting growth factor in forest systems. Additionally, ambient soil nutrient levels in our study were quite low (Coleman et al. 2004b); thus, these growth responses further support our initial hypothesis. Both sweetgum and loblolly pine are considered to be tolerant of a wide range of site conditions in the southeastern United States including droughty upland sites.

Our study suggests that, for the species tested, loblolly pine is slightly more drought tolerant than sweetgum; sweetgum did show a small response to irrigation, whereas loblolly pine actually showed a negative response. Also, sweetgum maintains greater leaf area during the growing season with greater transpiration rates (Samuelson 1998) compared with loblolly pine (Coleman et al. 2004b, Allen et al. 2005a), which can lead to increased water loss during the hot summers in this region. However, the sweetgum irrigation response was subtle compared with that of more resource-demanding species having narrow, high-resource site requirements such as cottonwood and sycamore (Coyle and Coleman 2005). Three-year-old cottonwood and sycamore production increased $81 \%$ and $119 \%$, respectively, in response to irrigation only, compared with a $9 \%$ increase in 4-year-old sweetgum. Only certain sweetgum biomass components were positively affected by irrigation, but most cottonwood and sycamore biomass components showed increased biomass (Coyle and Coleman 2005). In the southeastern United States, the effects of irrigation on sweetgum growth and biomass accumulation vary. For example, sweetgum growth nearly doubled with irrigation in southeastern Georgia (Allen et al. 2005b), but only leaf biomass was positively affected in southwestern Georgia (Samuelson 1998). In Alabama, irrigation had no effect on sweetgum growth (Lockaby et al. 1997). The response of sweetgum suggests that it is more tolerant of low water availability than the other hardwoods and, in this regard, more closely groups functionally as drought tolerant with the softwood loblolly pine. Nonetheless, there is a response to irrigation in sweetgum that is absent in loblolly pine. Therefore, from a functional, ecological perspective, sweetgum is similar to loblolly pine because of its very minimal response to irrigation, and yet the fact that it responds at all makes it unique as well.

Irrigation in dry climates often elicits a positive growth response from commercial timber species; however, the effects on drought-tolerant genera, such as Pinus, are variable. Irrigation has been shown to increase the growth of Monterey pine (Pinus radiata D. Don) (Myers et al. 1996) and longleaf pine (Pinus palustris Mill.) (Prior et al. 1997). However, the effects of irrigation on loblolly pine growth are inconsistent. For example, neither diameter nor biomass was significantly increased by the application of irrigation in Florida (Johnson 1990) or Georgia (Allen et al. 2005a). However, some loblolly pine studies in the southeastern United States have shown positive growth responses to irrigation (Albaugh et al. 1998; Samuelson et al. 2004). In a comparison of a number of similar irrigation by fertilization studies, Linder (1989) concluded that nutrition is the major factor limiting production; however, in arid regions, production potential cannot be achieved without irrigation (e.g., Linder 1989). This does not appear to be the case for many studies conducted with loblolly pine in the humid southeastern United States.

This is a unique study in that we provide detailed aboveand below-ground biomass for intensively managed sweetgum receiving both irrigation and fertilization treatments. Annual sweetgum growth has been reported as linear (Buckner and Maki 1977), whereas loblolly pine growth is known to increase exponentially after the second or third growing seasons (Adegbidi et al. 2004; Samuelson et al. 2004). We observed a similar response: sweetgum was substantially larger than loblolly pine after two growing seasons, but the difference was nearly nonexistent after season four.

Fertilization was the dominant driver of sweetgum pro- 
Table 4. Multiple regression results for comparisons of root versus shoot.

\begin{tabular}{|c|c|c|c|c|c|c|c|}
\hline Tissue type & Species & Variable & $\begin{array}{l}\text { Parameter } \\
\text { estimate }\end{array}$ & $F$ & $P$ & Partial $R^{2}$ & Model $R^{2}$ \\
\hline \multirow[t]{4}{*}{ Woody $^{a}$} & \multirow[t]{2}{*}{ Sweetgum } & Biomass & 0.912 & 1229.18 & $<0.0001$ & 0.982 & 0.982 \\
\hline & & Fertilization & 0.001 & 4.48 & 0.0464 & 0.003 & 0.986 \\
\hline & \multirow{2}{*}{ Loblolly pine } & Biomass & 0.938 & 3460.23 & $<0.0001$ & 0.994 & 0.994 \\
\hline & & Fertilization & -0.001 & 3.90 & 0.0615 & 0.001 & 0.995 \\
\hline \multirow{4}{*}{ Ephemeral $^{b}$} & \multirow[t]{2}{*}{ Sweetgum } & Biomass & 0.423 & 45.01 & $<0.0001$ & 0.672 & 0.672 \\
\hline & & Fertilization & 0.003 & 3.36 & 0.0809 & 0.045 & 0.717 \\
\hline & \multirow[t]{2}{*}{ Loblolly pine } & Biomass & 0.754 & 78.87 & $<0.0001$ & 0.782 & 0.782 \\
\hline & & Fertilization & na & na & na & na & na \\
\hline \multirow[t]{4}{*}{ Woody and ephemeral } & \multirow[t]{2}{*}{ Sweetgum } & Biomass & 0.743 & 331.86 & $<0.0001$ & 0.938 & 0.938 \\
\hline & & Fertilization & 0.002 & 6.93 & 0.0156 & 0.015 & 0.953 \\
\hline & \multirow[t]{2}{*}{ Loblolly pine } & Biomass & 0.918 & 847.43 & $<0.0001$ & 0.975 & 0.975 \\
\hline & & Fertilization & na & na & na & na & na \\
\hline
\end{tabular}

Note: na: factor not applicable for model inclusion.

"Woody tissues: branch, bark, wood, stump, and coarse roots.

${ }^{b}$ Ephemeral tissues: fine roots and leaves.

Table 5. Allometric coefficient, $k^{\prime}$, for various root and shoot components compared among treatments for each species during dormancy.

\begin{tabular}{|c|c|c|c|}
\hline Tissue type & Treatment & Sweetgum & Loblolly pine \\
\hline \multirow{4}{*}{$\begin{array}{l}\text { Total root versus total } \\
\text { shoot }\end{array}$} & $\mathrm{C}$ & $0.90 \mathrm{a}$ & 0.95 \\
\hline & I & $0.86 a$ & 0.84 \\
\hline & $\mathrm{F}$ & $0.63 b$ & 0.96 \\
\hline & IF & $0.70 \mathrm{~b}$ & 0.93 \\
\hline \multirow{4}{*}{$\begin{array}{l}\text { Woody root }{ }^{a} \text { versus } \\
\text { woody shoot }{ }^{b}\end{array}$} & $\mathrm{C}$ & $0.96 a$ & $0.96 \mathrm{a}$ \\
\hline & I & $1.03 \mathrm{a}$ & $0.88 b$ \\
\hline & $\mathrm{F}$ & $0.84 \mathrm{~b}$ & $0.94 \mathrm{ab}$ \\
\hline & IF & $0.93 a$ & $1.00 \mathrm{a}$ \\
\hline \multirow[t]{4}{*}{ Fine root versus leaf } & $\mathrm{C}$ & $0.66 a$ & 0.78 \\
\hline & I & $0.48 \mathrm{ab}$ & 0.63 \\
\hline & $\mathrm{F}$ & $0.36 \mathrm{ab}$ & 0.85 \\
\hline & IF & $0.22 b$ & 0.74 \\
\hline
\end{tabular}

Note: Treatments with the same letter have statistically equal $k$ '.

${ }^{a}$ Woody root, stump + coarse root.

${ }^{b}$ Woody shoot, branch + bark + wood.

ductivity in this study. Sweetgum aboveground growth was $79 \%$ greater in fertilized trees compared with nonfertilized trees, primarily because of an increase in wood biomass. Greater relative treatment differences have been reported (Samuelson 1998; Allen et al. 2005a), but maximum mean annual stem production in our study was high compared with most reports from the southeastern United States (Table 6), including several employing higher fertilization rates. Only Allen et al. (2005a) reported greater mean annual stem production rates, but these trees were older, more heavily stocked, and received a higher rate of fertilization.

Fertilized loblolly pine accumulated at least $51 \%$ more biomass than their unfertilized counterparts in every tissue fraction. Stem biomass was $96 \%$ greater in fertilized treatments compared with nonfertilized treatments in our study. Total aboveground production for 4-year-old loblolly pine receiving fertilization and herbicide treatments ranges from
Fig. 3. Allometric relationships for sweetgum (A) total biomass and (B) ephemeral tissues in response to fertilization treatments. All tissue fractions are natural log transformed plot means. The allometric coefficient, $k^{\prime}$, is the slope of the linear regression. Plot means from both 2001 and 2003 are included in the figure.
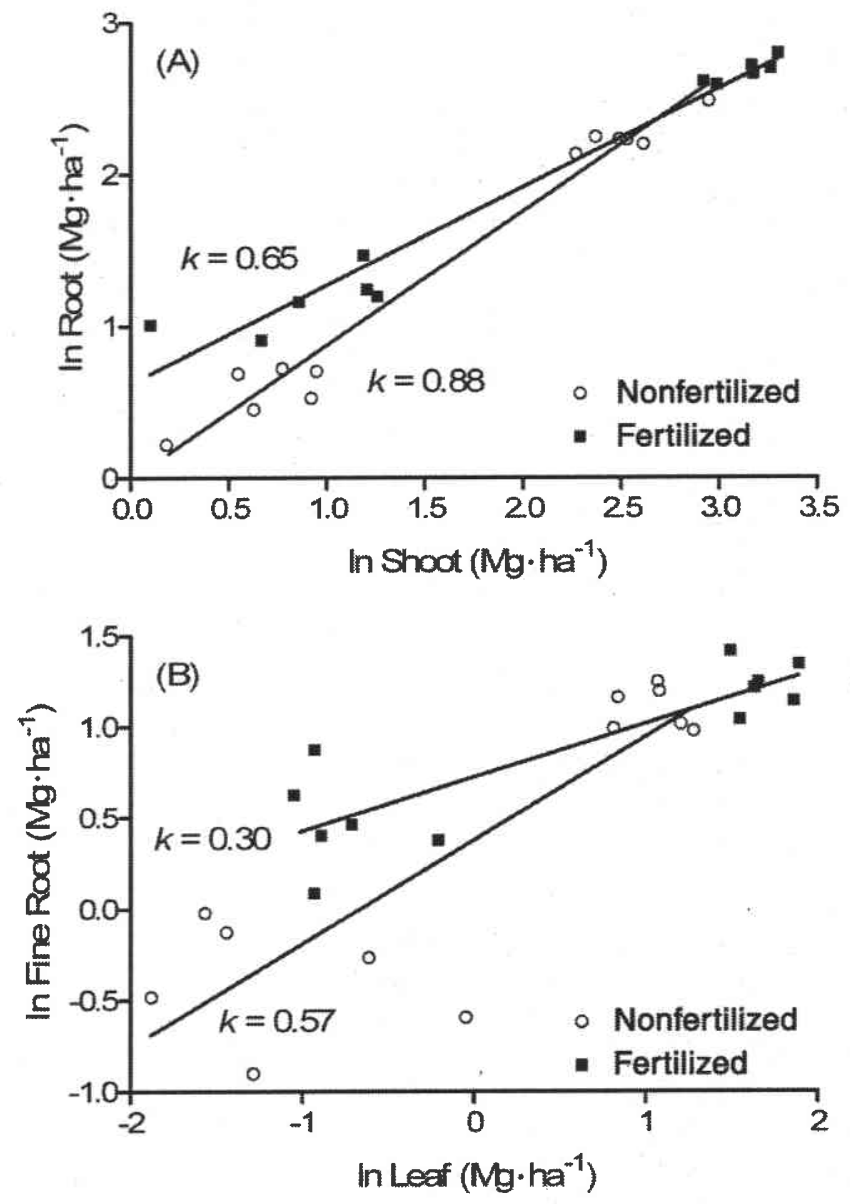

(C) 2008 NRC Canada 
Table 6. Reported maximum stem growth of intensively managed sweetgum in the southeastern United States.

\begin{tabular}{|c|c|c|c|c|c|c|c|c|c|c|}
\hline State & 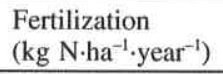 & $\begin{array}{l}\text { Ages at fertilizer } \\
\text { application (years) }\end{array}$ & $\begin{array}{l}\mathrm{DBH} \\
(\mathrm{cm})\end{array}$ & $\begin{array}{l}\text { Height } \\
(\mathrm{m})\end{array}$ & $\begin{array}{l}\text { BA } \\
\left(\mathrm{m}^{2} \cdot \mathrm{ha}^{-1}\right)\end{array}$ & $\begin{array}{l}\text { Stem production } \\
\left(\mathrm{Mg} \cdot \mathrm{ha}^{-1} \cdot \text { year }^{-1}\right)\end{array}$ & $\begin{array}{l}\text { Stem volume } \\
\left(\mathrm{m}^{3} \cdot \mathrm{ha}^{-1} \cdot \text { year }^{-1}\right)\end{array}$ & $\begin{array}{l}\text { Stocking } \\
\left(\text { trees } \cdot \mathrm{ha}^{-1}\right)\end{array}$ & $\begin{array}{l}\text { Age } \\
\text { (years) }\end{array}$ & Reference \\
\hline Alabama & $42^{a}$ & 1 & 4.4 & 3.4 & 1.2 & $0.6^{c}$ & 1.3 & 791 & 4 & Lockaby et al. 1997 \\
\hline Georgia & $66^{a}$ & $1-2$ & $6.8^{b}$ & 3.0 & $4.1^{b}$ & 1.0 & $2.2^{c}$ & 1126 & 2 & Samuelson 1998 \\
\hline Georgia & $85^{a}$ & $1-6$ & 10.5 & 9.1 & 15.5 & 5.2 & 29.9 & 1790 & 6 & Allen et al. $2005 a$ \\
\hline Georgia & $135^{a}$ & $1-5$ & 9.4 & 6.1 & 8.0 & 3.2 & 12.5 & 1157 & 5 & Gresham and Williams 2002 \\
\hline Mississippi & 44 & 2,4 & 9.3 & 8.4 & 7.1 & 1.5 & 2.8 & 1078 & 9 & Nelson and Switzer 1990 \\
\hline South Carolina & $60^{a}$ & $1-4$ & 8.4 & 6.8 & 7.6 & 3.5 & 16.0 & 1333 & 4 & This study \\
\hline South Carolina & 63 & $2,4,6$ & 8.5 & 7.0 & 7.9 & 2.3 & 8.4 & 1400 & 6 & Scott et al. 2004 \\
\hline South Carolina & 65 & $1-3,5,7$ & 7.0 & 5.5 & 7.1 & 2.5 & 7.1 & 1852 & 7 & Davis and Trettin 2006 \\
\hline
\end{tabular}

${ }^{a}$ Study also received irrigation.

${ }^{b}$ Groundline diameter was reported; thus, basal area is calculated from groundline diameter.

${ }^{c}$ Value was calculated using a specific gravity for sweetgum wood + bark of 0.454 (Clark et al. 1985).

Table 7. Reported stem growth of young intensively managed loblolly pine in the southeastern United States.

\begin{tabular}{|c|c|c|c|c|c|c|c|c|c|c|}
\hline State & $\begin{array}{l}\text { Fertilization } \\
\left(\mathrm{kg} \mathrm{N}^{-1} \mathrm{ha}^{-1} \cdot \mathrm{year}^{-1}\right)\end{array}$ & $\begin{array}{l}\text { Age at fertilizer } \\
\text { application (years) }\end{array}$ & $\begin{array}{l}\text { DBH } \\
(\mathrm{cm})\end{array}$ & $\begin{array}{l}\text { Height } \\
\text { (m) }\end{array}$ & $\begin{array}{l}\text { BA } \\
\left(m^{2} \cdot h a^{-1}\right)\end{array}$ & $\begin{array}{l}\text { Stem production } \\
\left(\mathrm{Mg} \cdot \mathrm{ha}^{-1} \cdot \text { year }^{-1}\right)\end{array}$ & $\begin{array}{l}\text { Stem volume } \\
\left(\mathrm{m}^{3} \cdot \mathrm{ha}^{-1} \cdot \text { year }^{-1}\right)\end{array}$ & $\begin{array}{l}\text { Initial stocking } \\
\left(\text { trees }^{\prime} \mathrm{ha}^{-1}\right)\end{array}$ & $\begin{array}{l}\text { Age } \\
\text { (years) }\end{array}$ & Reference(s) \\
\hline Florida & 60 & $1-4$ & 9.4 & 5.4 & 10.0 & 3.9 & $8.7^{b}$ & 1453 & 4 & Colbert et al. 1990 \\
\hline Florida & $60^{a}$ & $1-4$ & 10.1 & 5.6 & 11.9 & $3.7^{b}$ & 8.3 & 1481 & 4 & Swindell et al. 1988 \\
\hline Georgia & 30 & 1,3 & 10.6 & 7.0 & 13.2 & 11.8 & & 1495 & 4 & Adegbidi et al. 2002, 2005 \\
\hline Georgia & $85^{a}$ & $1-6$ & 13.7 & 10.9 & 26.4 & 8.8 & $19.6^{b}$ & 1790 & 6 & Allen et al. $2005 a$ \\
\hline Georgia & $90^{a}$ & $1-6$ & 17.2 & & 25.0 & 8.0 & $17.8^{b}$ & 1070 & 6 & Samuelson et al. 2004 \\
\hline Louisiana & 35 & $1-2$ & 11.8 & 7.2 & 17.5 & $5.7^{b}$ & 12.6 & 1600 & 5 & Haywood et al. 1997 \\
\hline South Carolina & $60^{a}$ & $1-4$ & 9.8 & 6.4 & 10.5 & 3.7 & 8.0 & 1333 & 4 & This study \\
\hline Virginia & 61 & $1-5$ & 7.9 & 4.9 & 10.7 & & & 2178 & 5 & Amishev and Fox 2006 \\
\hline
\end{tabular}

${ }^{a}$ Study also received irrigation.

${ }^{b}$ Value was calculated using a specific gravity value of 0.45 ; this value has been reported for fertilized 10-year-old $P$. taeda (Albaugh et al. 2004). 
Fig. 4. Allometric relationship between loblolly pine root $\left(M_{\mathrm{R}}\right)$ and shoot $\left(M_{\mathrm{S}}\right)$ biomass. Data from this study are plotted with those taken from the published reports where aboveground and belowground biomass is available for field studies.

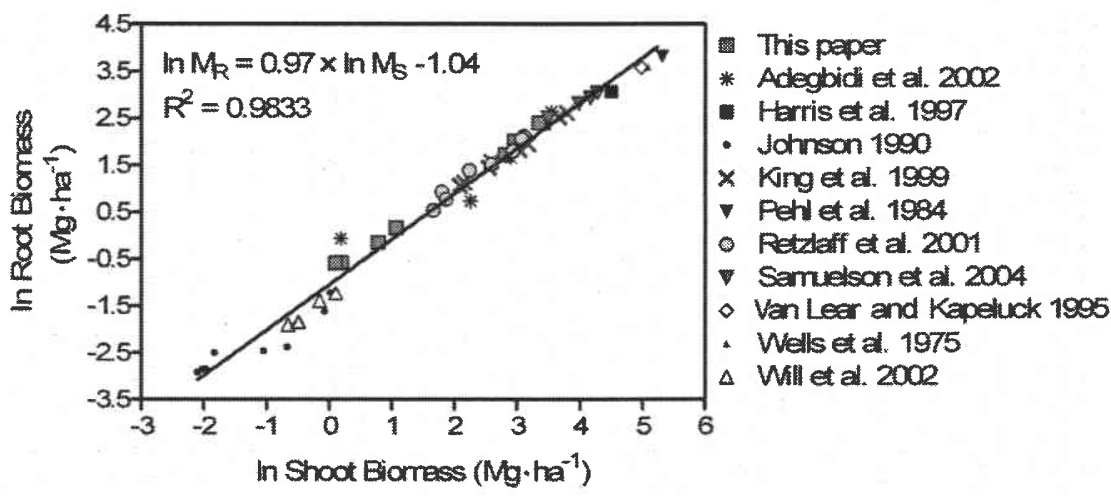

2-3 Mg.ha-1.year-1 (Borders et al. 2004; Martin and Jokela 2004), to $10 \mathrm{Mg} \cdot \mathrm{ha}^{-1} \cdot \mathrm{year}^{-1}$ (Samuelson et al. 2004), and up to $21 \mathrm{Mg} \cdot \mathrm{ha}^{-1} \cdot \mathrm{year}^{-1}$ (Adegbidi et al. 2005). Our aboveground production of $7.7 \mathrm{Mg} \cdot \mathrm{ha}^{-1}$.year ${ }^{-1}$ fell within this reported range. Stem production in our study compared favorably with other intensively managed loblolly pine studies of similar age in the southeastern United States (Table 7). Increased fertilization rates (Samuelson et al. 2004; Allen et al. 2005a) or greater stocking levels (Haywood et al. 1997; Adegbidi et al. 2002, 2005; Allen et al. 2005a) may be reasons why other studies showed greater stem production rates. Production and volume accumulation are expected to continue increasing until intertree competition exceeds a basal area threshold of $25 \mathrm{~m}^{2} \cdot \mathrm{ha}^{-1}$ (Jokela et al. 2004). Pine leaf biomass increased $16 \%$ because of fertilization in our study. Borders et al. (2004) observed a similar positive response $(18 \%)$; however, these responses were relatively small compared with increases of $63 \%$ (Martin and Jokela 2004) and 72\% (Colbert et al. 1990) observed elsewhere. Samuelson et al. (2004) observed a $120 \%$ increase in leaf biomass, but their study included pesticide application on fertilized plots and no pesticides on the control treatment. We used different genotypes of loblolly pine in our study compared with other studies, and this may also explain observed foliage biomass and production differences.

\section{Effect of resource amendments on biomass distribution}

Our second hypothesis that greater resource availability would lead to increased aboveground biomass fractions was confirmed for fertilized sweetgum but rejected for pine. Previous studies have suggested that greater aboveground production due to higher resource availability results from shifts in the proportion of biomass from roots to stem (Johnson 1990; Li et al. 1991; Haynes and Gower 1995). However, most studies do not consider the stage of stand development and simply compare chronologically similar trees. As previously shown with cottonwood and sycamore on this site (Coyle and Coleman 2005) and with loblolly pine (Ledig et al. 1970; King et al. 1999; Will et al. 2002) and eucalyptus (Barton and Montagu 2006) on other sites, stand development, not cultural treatment, is the primary factor driving the shift in the proportion of belowground biomass (Fig. 4; Table 5). Increased resource amendments contribute to faster stand development, which appears to be a treatment effect on RMF in stands of comparable age (Coyle and Coleman 2005). However, as shown by Ledig et al. (1970); King et al. (1999), and Reich (2002), development is largely controlling changes in RMF. RMF declines as a function of total biomass in our data $(P<0.04)$ and is a direct consequence of $k$ being less than unity (Table 5). Similar developmental declines in RMF have been shown in several tree species, including loblolly pine (Bernardo et al. 1998; Albaugh et al. 2004; Coyle and Coleman 2005). Collectively, this information demonstrates the importance of accounting for development when considering the effect of resource availability on the proportion of belowground biomass fractions. Increased growth caused by greater nutrient and water availability will advance development, which will cause a decline in RMF by itself provided $k$ is below unity. If similar aged stands are compared without regard to development, all of the decline in relative belowground production may be erroneously attributed to the applied treatment. To separate the relative impact of development from treatment effects, the allometric approach can be used.

Allometric analysis of our experimental data indicated that there was an effect of fertilization on the proportion of belowground biomass in sweetgum but not in pine. Despite the fact that only $2 \%$ of the variation in sweetgum total root versus total shoot was explained by fertilization, it caused a $30 \%$ decline in $k^{\prime}$, indicating that there was an important shift in belowground biomass proportions due to fertilization. Of the five genotypes examined on this study site (see Coyle and Coleman 2005 for comparison with two eastern cottonwood genotypes and sycamore), sweetgum was the only one to show decreased $k^{\prime}$ with fertilization; in the other hardwood species showing a response, $k^{\prime}$ actually increased. A similar decline in $k^{\prime}$ was observed for sweetgum fine root versus foliage; such ephemeral tissues are thought to be most responsive to resource availability (Landsberg and Gower 1997). We conclude that increased aboveground production due to greater resource availability is largely due to enhanced development among all the species examined in this study and not the result of a decrease in resourceinduced belowground carbon allocation.

Loblolly pine maintains surprisingly consistent above- and below-ground proportions. There were no differences in RMF or $k^{\prime}$, even though there was a $61 \%$ increase in total biomass between nonfertilized and fertilized plots. Stability 
of belowground proportions was confirmed by comparing data from other whole tree biomass studies for loblolly pine. Despite a wide physiographic range and large genetic variation, compiled literature reports show allometric proportions are extremely uniform (Fig. 4). The $k^{\prime}$ for these data is near unity, which indicates that root and shoot biomass scale isometrically, confirming developed theory (Enquist and Niklas 2002). Such a consistent scaling factor would be useful for estimating belowground mass based on aboveground mass. The isometric scaling theory has been questioned based on the accuracy of belowground information because of missing fine root fractions during sampling (Robinson 2004). To minimize questions of belowground data accuracy, we were careful to sample all root classes. Our data confirm that isometric scaling is within the range of uncertainty, and the values fall in line with literature data using various levels of belowground detail. Given that $k^{\prime}$ is near unity (i.e., the nonlinear form of eq. 1 is a straight line with $k^{\prime}=1$ ), it is then possible to simply estimate belowground biomass based on the multiplier, $a^{\prime}$. Using this approach, Albaugh et al. (2006) determined that coarse root biomass could be estimated as one-half of stem biomass. Our results similarly demonstrate that belowground biomass can be estimated as one-third of aboveground biomass. However, it should be emphasized that these simplified relationships assume that $k^{\prime}$ is unity.

Despite the convenience of predicting belowground biomass as one-third of aboveground biomass assuming $k^{\prime}=1$, such an approach should be used with caution. The allometric equation is inherently nonlinear. We observed $k^{\prime}$ for pine to have a mean of 0.93 and a $95 \%$ confidence interval between 0.85 and 1.01. Assuming $k^{\prime}$ is unity and using the simplified estimate for root biomass as one-third of aboveground would result in a $40 \%$ overestimate of belowground biomass if actual $k^{\prime}=0.93$. Such uncertainty will have important commercial, legal, and political repercussions if carbon emission trading relies on such calculations for estimating belowground carbon sequestration. The questions of accurate belowground sampling methods and precise estimate for $k^{\prime}$ demonstrate the need for a more extensive effort to evaluate belowground biomass prior to relying on belowground biomass to decrease elevated atmospheric carbon through soil sequestration.

\section{Acknowledgements}

Funding was provided by the US Department of EnergySavannah River Operations office through the USDA Forest Service Savannah River and the Forest Service Southern Research Station under Interagency Agreement DE-IA09. 76SR00056; Department of Energy Oak Ridge National Laboratory Interagency Agreement 00-IA-11330135-221; Southern Research Station Research Work Units 4103, 4104, 4154, 4155, 4505, and 4703; and The Timber Company, Weyerhaeuser, Champion International, and Union Camp. Thanks to the many project technicians and staff at the USDA Forest Service Savannah River Forest Station, The University of Georgia, and Auburn University who made data collection possible. Thanks to Bernard Parresol and Stan Zarnoch, USDA Forest Service Southern Research Station, and Steve Hong, University of Wisconsin-Madison, for statistical consultation and advice. This manuscript was greatly improved by the comments of several anonymous reviewers.

\section{References}

Adegbidi, H.G., Jokela, E.J., Comerford, N.B., and Barros, N.F. 2002. Biomass development for intensively managed loblolly pine plantations growing on Spodosols in the southeastern USA. For. Ecol. Manage. 167: 91-102. doi:10.1016/S0378-1127(01) 00691-0.

Adegbidi, H.G., Comerford, N.B., Jokela, E.J., and Barros, N.F. 2004. Root development of young loblolly pine in Spodosols in southeast Georgia. Soil Sci. Soc. Am. J. 68: 596-604.

Adegbidi, H.G., Jokela, E.J., and Comerford, N.B. 2005. Factors influencing production efficiency of intensively managed loblolly pine plantations in a 1- to 4-year-old chronosequence. For. Ecol. Manage. 218: 245-258. doi:10.1016/j.foreco.2005.08.016.

Albaugh, T.J., Allen, H.L., Dougherty, P.M., Kress, L.W., and King, J.S. 1998. Leaf area and above- and belowground growth responses of loblolly pine to nutrient and water additions. For. Sci. 44: 317-328.

Albaugh, T.J., Allen, H.L., Dougherty, P.M., and Johnsen, K.H. 2004. Long term growth responses of loblolly pine to optimal nutrient and water resource availability. For. Ecol. Manage. 192: 3-19. doi:10.1016/j.foreco.2004.01.002.

Albaugh, T., Allen, H., and Kress, L. 2006. Root and stem partitioning of Pinus taeda. Trees (Berl.), 20: 176-185. doi:10.1007/ s00468-005-0024-4.

Allen, C.B., Will, R.E., and Jacobson, M.A. 2005a. Production efficiency and radiation use efficiency of four tree species receiving irrigation and fertilization. For. Sci. 51: 556-569.

Allen, C.B., Will, R.E., McGarvey, R.C., Coyle, D.R., and Coleman, M.D. 2005b. Radiation-use efficiency and gas exchange responses to water and nutrient availability in irrigated and fertilized stands of sweetgum and sycamore. Tree Physiol. 25: 191200. PMID:15574400.

Amishev, D.Y., and Fox, T.R. 2006. The effect of weed control and fertilization on survival and growth of four pine species in the Virginia Piedmont. For. Ecol. Manage. 236: 93-101. doi:10. 1016/j.foreco.2006.08.339.

Axelsson, E., and Axelsson, B. 1986. Changes in carbon allocation patterns in spruce and pine trees following irrigation and fertilization. Tree Physiol. 2: 189-204. PMID:14975853.

Barton, C.V.M., and Montagu, K.D. 2006. Effect of spacing and water availability on root:shoot ratio in Eucalyptus camaldulensis. For. Ecol. Manage. 221: 52-62.

Bernardo, A.L., Reis, M.G.F., Reis, G.G., Harrison, R.B., and Firme, D.J. 1998. Effect of spacing on growth and biomass distribution in Eucalyptus camaldulensis, E. pellita and E. urophylla plantations in southeastern Brazil. For. Ecol. Manage. 104: 1-13. doi:10.1016/S0378-1127(97)00199-0.

Borders, B.E., Will, R.E., Markewitz, D., Clark, A., Hendrick, R., Teskey, R.O., and Zhang, Y. 2004. Effect of complete competition control and annual fertilization on stem growth and canopy relations for a chronosequence of loblolly pine plantations in the lower coastal plain of Georgia. For. Ecol. Manage. 192: 21-37. doi:10.1016/j.foreco.2004.01.003.

Buckner, E., and Maki, T.E. 1977. Seven-year growth of fertilized and irrigated yellow poplar, sweetgum, northern red oak, and loblolly pine planted on two sites. For. Sci. 23: 402-410.

Burnham, K.P., and Anderson, D.R. 1998. Model selection and inference: a practical information-theoretic approach. SpringerVerlag, NewYork.

Clark, A., Phillips, D.R., and Fredrick, D.J. 1985. Weight, volume, 
and physical properties of major hardwood species in the Gulf and Atlantic Coastal Plains. USDA For. Serv Southeast. For. Range Exp. Stn. Res. Pap. SE-250.

Colbert, S.R., Jokela, E.J., and Neary, D.G. 1990. Effect of annual fertilization and sustained weed control on dry matter partitioning, leaf area, and growth efficiency of juvenile loblolly and slash pine. For. Sci. 36: 995-1014.

Coleman, M.D. 2007. Spatial and temporal patterns of root distribution in developing stands of four woody crop species grown with drip irrigation and fertilization. Plant Soil, 299: 195-213. doi:10.1007/s11104-007-9375-5.

Coleman, M.D., Friend, A.L., and Kern, C.C. 2004a. Carbon allocation and nitrogen acquisition in a developing Populus deltoides plantation. Tree Physiol. 24: 1347-1357. PMID:15465697.

Coleman, M.D., Coyle, D.R., Blake, J., Britton, K., Buford, M., Campbell, R.G., Cox, J., Cregg, B., Daniels, D., Jacobson, M., Johnsen, K., McDonald, T., McLeod, K., Nelson, E., Robison, D., Rummer, R., Sanchez, F., Stanturf, J., Stokes, B., Trettin, C., Tuskan, J., Wright, L., and Wullschleger, S. 2004b. Production of short-rotation woody crops grown with a range of nutrient and water availability: establishment report and first-year responses. USDA For. Serv. Gen. Tech. Rep. SRS-72.

Coyle, D.R., and Coleman, M.D. 2005. Forest production responses to irrigation and fertilization are not explained by shifts in allocation. For. Ecol. Manage. 208: 137-152. doi:10.1016/j.foreco. 2004.11.022.

Davis, A.A., and Trettin, C.C. 2006. Sycamore and sweetgum plantation productivity on former agricultural land in South Carolina. Biomass Bioenergy, 30: 769-777. doi:10.1016/j.biombioe. 2005.08.001.

Enquist, B.J., and Niklas, K.J. 2002. Global allocation rules for patterns of biomass partitioning in seed plants. Science (Washington, D.C.), 295: 1517-1520. doi:10.1126/science.1066360. PMID:11859193.

Farnum, P., Timmis, R., and Kulp, J.L. 1983. Biotechnology of forest yield. Science (Washington, D.C.), 219: 694-702. doi:10. 1126/science.219.4585.694. PMID:17814031.

Fox, T.R., Allen, H.L., Albaugh, T.J., Rubilar, R., and Carlson, C.A. 2006. Forest fertilization in southern pine plantations. Better Crops Plant Food, 90: 12-15.

Gresham, C.A., and Williams, T.M. 2002. Biomass, nitrogen, and phosphorus accumulation in 4-year-old intensively managed loblolly pine and sweetgum plantations. In Proceedings of the Eleventh Biennial Southern Silvicultural Research Conference, 1922 Mar. 2001, Knoxville, Tenn. Edited by K.W. Oucalt. USDA For. Serv. Gen Tech. Rep. SRS-48. pp. 3-6.

Harris, W.F., Kinerson, R.S., Jr., and Edwards, N.T. 1977. Comparison of belowground biomass of natural deciduous forest and loblolly pine plantations. Pedobiologia (Jena), 17: 369-381.

Haynes, B.E., and Gower, S.T. 1995. Belowground carbon allocation in unfertilized and fertilized red pine plantations in northern Wisconsin. Tree Physiol. 15: 317-325. PMID:14965955.

Haywood, J.D., Tiarks, A.E., and Sword, M.A. 1997. Fertilization, weed control, and pine litter influence loblolly pine stem productivity and root development. New For. 14: 233-249.

Hunt, R. 1978. Plant growth analysis. Edward Arnold Ltd., London.

Johnson, J.D. 1990. Dry-matter partitioning in loblolly and slash pine: effects of fertilization and irrigation. For. Ecol. Manage. 30: $147-157$. doi:10.1016/0378-1127(90)90133-V.

Jokela, E.J., Dougherty, P.M., and Martin, T.A. 2004. Production dynamics of intensively managed loblolly pine stands in the southern United States: a synthesis of seven long-term experi- ments. For. Ecol. Manage. 192: 117-130. doi:10.1016/j.foreco. 2004.01.007.

Kenward, M.G., and Roger, J.H. 1997. Small sample inference for fixed effects from restricted maximum likelihood. Biometrics, 53: 983-997. doi:10.2307/2533558. PMID:9333350.

King, J.S., Albaugh, T.J., Allen, H.L., and Kress, L.W. 1999. Stand-level allometry in Pinus taeda as affected by irrigation and fertilization. Tree Physiol. 19: 769-778. PMID:10562392.

Landsbèrg, J.J., and Gower, S.T. 1997. Applications of physiological ecology to forest management. Academic Press, New York.

Ledig, F.T., Bormann, F.H., and Wenger, K.F. 1970. The distribution of dry matter growth between shoot and roots in loblolly pine. Bot. Gaz. 131: 349-359. doi:10.1086/336552.

Lemus, R., and Lal, R. 2005. Bioenergy crops and carbon sequestration. Crit. Rev. Plant Sci. 24: 1-21. doi:10.1080/ 07352680590910393.

Li, B., Allen, H.L., and McKeand, S.E. 1991. Nitrogen and family effects on biomass allocation of loblolly pine seedlings. For. Sci. 37: 271-283.

Linder, S. 1989. Nutritional control of forest yield. In Nutrition of trees. The Marcus Wallenberg Foundation, Falun, Sweden. pp 62-87.

Littell, R.C., Milliken, G.A., Stroup, W.W., and Wolfinger, R.D. 2006. SAS system for mixed models. 2nd ed. SAS Institute Inc., Cary, N.C.

Lockaby, B.G., Clawson, R.G., and Baker, T. 1997. Response of three hardwood species to irrigation and fertilization on an upland site. South. J. Appl. For. 21: 123-129.

Martin, T.A., and Jokela, E.J. 2004. Stand development and production dynamics of loblolly pine under a range of cultural treatments in north-central Florida USA. For. Ecol. Manage. 192: 39-58. doi:10.1016/j.foreco.2004.01.004.

Mead, D.J. 2005. Forests for energy and the role of planted trees. Crit. Rev. Plant Sci. 24: 407-421. doi:10.1080/ 07352680500316391.

Myers, B.J., Theiveyanathan, S., O'Brien, N.D., and Bond, W.J. 1996. Growth and water use of Eucalyptus grandis and Pinus radiata plantations irrigated with effluent. Tree Physiol. 16: 211-219. PMID:14871765.

Nelson, L.E., and Switzer, G.L. 1990. Sweetgum half-sib seed source response to nitrogen and phosphorus fertilization in Mississippi. Soil Sci. Soc. Am. J. 54: 871-878.

Nelson, L.E., Switzer, G.L., and Shelton, M.G. 1995. Aboveground net primary productivity and nutrient content of fertilized plantation sweetgum. Soil Sci. Soc. Am. J. 59: 925-932.

Oren, R., Ellsworth, D.S., Johnsen, K.H., Phillips, N., Ewers, B.E., Maier, C.A., Schafer, K.V.R., McCarthy, H., Hendrey, G., McNulty, S.G., and Katul, G.G. 2001. Soil fertility limits carbon sequestration by forest ecosystems in a $\mathrm{CO}_{2}$-enriched atmosphere. Nature (Lond.), 411: 469-472. doi:10.1038/35078064. PMID:11373677.

Parresol, B.R. 1999. Assessing tree and stand biomass: a review with examples and critical comparisons. For. Sci. 45: 573-593.

Pehl, C.E., Tuttle, C.L., Houser, J.N., and Moehring, D.M. 1984. Total biomass and nutrients of 25-year-old loblolly pines (Pinus taeda L.). For. Ecol, Manage. 9: 155-160. doi:10.1016/03781127(84)90044-6.

Prior, S.A., Runion, G.B., Mitchell, R.J., Rogers, H.H., and Amthor, J.S. 1997. Effects of atmospheric $\mathrm{CO}_{2}$ on longleaf pine: productivity and allocation as influenced by nitrogen and water. Tree Physiol. 17: 397-405. PMID:14759848.

Reich, P.B. 2002. Root-shoot relations: optimality in acclimation and adaptation or the "Emperor's new clothes"? In Plant roots: 
the hidden half. Edited by Y. Waisel, A. Eshel, and U. Kafkafi. Marcel Dekker, New York. pp. 205-220.

Retzlaff, W.A., Handest, J.A., O'Malley, D.M., McKeand, S.E., and Topa, M.A. 2001. Whole-tree biomass and carbon allocation of juvenile trees of loblolly pine (Pinus taeda): influence of genetics and fertilization. Can. J. For. Res. 31: 960-970. doi:10. 1139/cjfr-31-6-960.

Robinson, D. 2004. Scaling the depths: below-ground allocation in plants, forests and biomes. Funct. Ecol. 18: 290-295. doi:10. 1111/j.0269-8463.2004.00849.x.

Samuelson, L.J. 1998. Influence of intensive culture on leaf net photosynthesis and growth of sweetgum and loblolly pine seedlings. For. Sci. 44: 308-316.

Samuelson, L.J., Johnsen, K., and Stokes, T. 2004. Production, allocation, and stemwood growth efficiency of Pinus taeda L. stands in response to 6 years of intensive management. For. Ecol. Manage. 192: 59-70. doi:10.1016/j.foreco.2004.01.005.

Schabenberger, O., Gregoire, T.J., and Kong, F. 2000. Collection of simple effects and their relationship to main effects and interactions in factorials. Am. Stat. 54: 210-214. doi:10.2307/2685592.

Scott, D.A., Burger, J.A., Kaczmarek, D.J., and Kane, M.B. 2004. Growth and nutrition response of young sweetgum plantations to repeated nitrogen fertilization on two site types. Biomass Bioenergy, 27: 313-325. doi:10.1016/j.biombioe.2004.02.003.

Sedjo, R.A., and Botkin, D. 1997. Using forest plantations to spare natural forests. Environment, 39: 14-20, 30.

Shan, J., Morris, L.A., and Hendrick, R.L. 2001. The effects of management on soil and plant carbon sequestration in slash pine plantations. J. Appl. Ecol. 38: 932-941. doi:10.1046/j. 1365-2664.2001.00648.x.

Siry, J.P., and Bailey, R.L. 2003. Increasing southern pine growth and its implications for regional wood supply. For. Prod. J. 53: 32-37.

Stanturf, J.A., Kellison, R.C., Broerman, F.S., and Jones, S.B. 2003. Productivity of southern pine plantations: where are we and how did we get here? J. For. 101: 26-31.

Swindell, B.F., Neary, D.G., Comerford, N.B., Rockwood, D.L., and Blakeslee, G.M. 1988. Fertilization and competition control accelerate early southern pine growth on flatwoods. South. J. Appl. For. 12: 116-121.

Van Lear, D.H., and Kapeluck, P.R. 1995. Above- and belowstump biomass and nutrient content of a mature loblolly pine plantation. Can. J. For. Res. 25: 361-367. doi:10.1139/x95-040.

Wells, C.G., Jorgensen, J.R., and Burnette, C.E. 1975. Biomass and mineral elements in a thinned loblolly pine plantation at age 16 . USDA For. Serv. Southeastern For. Exp. Stn. Res. Pap. SE-126.

Will, R.E., Wheeler, M.J., Markewitz, D., Jacobson, M.A., and Shirley, A.M. 2002. II. Early loblolly pine stand response to tillage on the Piedmont and Upper Coastal Plain of Georgia: tree allometry, foliar nitrogen concentration, soil bulk density, soil moisture, and soil nitrogen status. South. J. Appl. For. 26: 190-196.

Woodbury, P.B., Smith, J.E., and Heath, L.S. 2007. Carbon sequestration in the U.S. forest sector from 1990 to 2010. For. Ecol. Manage. 241: 14-27. doi:10.1016/j.foreco.2006.12.008.

Zar, J.H. 1996. Biostatistical analysis. Prentice-Hall, Englewood Cliffs, N.J.

\section{Appendix A}

Table A1 appears on the next page. 
Table A1. Regression equations used for calculating biomass for 4-year-old trees in 2003.

\begin{tabular}{|c|c|c|c|c|c|c|c|}
\hline \multirow[b]{2}{*}{ Component } & \multirow[b]{2}{*}{ Treatment $^{a}$} & \multicolumn{3}{|c|}{ Sweetgum } & \multicolumn{3}{|l|}{ Loblolly pine } \\
\hline & & $\bar{a}$ & $b$ & $R^{2}$ & $\bar{A}$ & $b$ & $R^{2}$ \\
\hline \multirow[t]{4}{*}{ Branch } & $\mathrm{C}$ & 1.05 & 1.91 & 0.70 & $1.44 \times 10^{-3}$ & 3.33 & 0.99 \\
\hline & I & 0.04 & 2.65 & 0.98 & 0.04 & 2.59 & 0.99 \\
\hline & F & 7.43 & 1.47 & 0.78 & $1.87 \times 10^{-5}$ & 4.24 & 0.98 \\
\hline & IF & 0.05 & 2.57 & 0.94 & 5.97 & 1.46 & 0.73 \\
\hline \multirow[t]{4}{*}{ Bark } & $\mathrm{C}$ & 1.30 & 1.46 & 0.89 & 0.56 & 1.76 & 0.99 \\
\hline & I & 0.24 & 1.86 & 0.94 & 1.28 & 1.58 & 0.98 \\
\hline & F & 0.50 & 1.67 & 0.96 & $3.47 \times 10^{-5}$ & 3.93 & 0.96 \\
\hline & IF & 0.01 & 2.73 & 0.88 & $5.08 \times 10^{-5}$ & 3.78 & 0.98 \\
\hline \multirow[t]{4}{*}{ Wood } & $\mathrm{C}$ & 1.86 & 1.87 & 0.92 & 0.30 & 2.21 & 0.98 \\
\hline & I & 0.07 & 2.63 & 0.96 & 0.55 & 2.08 & 1.00 \\
\hline & $\mathrm{F}$ & 2.81 & 1.79 & 0.92 & $4.06 \times 10^{-4}$ & 3.68 & 0.98 \\
\hline & IF & 0.23 & 2.39 & 0.90 & $3.64 \times 10^{-3}$ & 3.19 & 1.00 \\
\hline \multirow[t]{4}{*}{ Stem } & $\mathrm{C}$ & 2.53 & 1.83 & 0.92 & 0.56 & 2.12 & 0.98 \\
\hline & I & 0.11 & 2.54 & 0.96 & 1.07 & 1.98 & 0.99 \\
\hline & $\mathrm{F}$ & 3.27 & 1.78 & 0.94 & $4.12 \times 10^{-4}$ & 3.73 & 0.98 \\
\hline & IF & 0.22 & 2.42 & 0.90 & $2.84 \times 10^{-3}$ & 3.28 & 0.99 \\
\hline \multirow[t]{4}{*}{ Total shoot ${ }^{b}$} & $\mathrm{C}$ & 3.56 & 1.86 & 0.89 & 0.80 & 2.24 & 1.00 \\
\hline & I & 0.15 & 2.58 & 0.98 & 1.43 & 2.11 & 1.00 \\
\hline & F & 8.80 & 1.66 & 0.96 & $2.61 \times 10^{-3}$ & 3.47 & 0.98 \\
\hline & IF & 0.27 & 2.47 & 0.92 & 0.63 & 2.26 & 0.98 \\
\hline \multirow[t]{4}{*}{ Stump } & $\mathrm{C}$ & 1.68 & 1.68 & 0.67 & 4.37 & 1.36 & 0.94 \\
\hline & I & 0.01 & 2.83 & 0.95 & 0.01 & 2.72 & 1.00 \\
\hline & F & 5.87 & 1.38 & 0.89 & 0.15 & 2.08 & 0.98 \\
\hline & IF & 47.88 & 0.88 & 0.44 & 0.35 & 1.92 & 0.97 \\
\hline \multirow[t]{4}{*}{ Coarse root } & $\mathrm{C}$ & 228.55 & 0.62 & 0.14 & 13.49 & 1.25 & 0.65 \\
\hline & I & 12.20 & 1.39 & 0.43 & 0.11 & 2.27 & 0.85 \\
\hline & $\mathrm{F}$ & 8.24 & 1.50 & 0.34 & 1.02 & 1.85 & 0.96 \\
\hline & IF & 0.03 & 2.76 & 0.37 & 438.59 & 0.50 & 0.23 \\
\hline \multirow[t]{4}{*}{ Total root ${ }^{c}$} & C & 98.93 & 0.93 & 0.52 & 17.04 & 1.29 & 0.80 \\
\hline & I & 4.95 & 1.67 & 0.63 & 0.07 & 2.50 & 0.95 \\
\hline & F & 13.65 & 1.46 & 0.53 & 1.08 & 1.91 & 0.97 \\
\hline & IF & 0.82 & 2.10 & 0.38 & 63.67 & 1.02 & 0.68 \\
\hline
\end{tabular}

Note: Regression equations were of the form $y=a x^{b}$, where $y$ is individual tree biomass $\left(\mathrm{g} \cdot \mathrm{m}^{-2}\right), a$ and $b$ are model-estimated parameters, and $x$ is $\mathrm{DBH}(\mathrm{mm})$. All equations are significant $(P<0.01)$

aTreatments are as follows: C, control; I, irrigation; F, fertilization; IF, irrigation + fertilization.

${ }^{b}$ Total shoot $=$ branch + bark + wood + leaf; leaf was included for loblolly pine, as it was part of the dormant harvest; sweetgum leaf litter could not be included in the analysis because of the sampling scheme.

'Total root = stump + coarse root; fine roots could not be included in the equation because of the sampling scheme. 